\section{Anencefalia numa perspectiva ética}

\section{Anencephalia from an ethical perspective}

Munir Massud 1
1 Programa de Doutoramento em Bioética. Faculdade de Medicina. Universidade do Porto. Alameda Prof. Hernâni Monteiro, 4200319. Porto, Portugal. E-mail: munirmassud@yahoo.com.br

\begin{abstract}
This article presents a brief review of anencephalia, a serious fetal defect of the central nervous system, from a bioethical point of view, founded on knowledge in modern embryology and cell biology. This issue has been the subject of much heated debate in many sectors of Brazilian society, as it touches on the question of abortion, religious beliefs and women's rights, regarding the woman's decision to continue an anencephalic pregnancy or not.
\end{abstract}

Key words Abortion, Brain death, Anencephaly

\section{Resumo}

Este artigo consta de uma revisão sumariada da anencefalia, um grave defeito embrionário do sistema nervoso central, sob o ponto de vista bioético, fundamentada em conhecimentos da embriologia e biologia celular modernas. Este tema tem sido alvo de debates acirrados em diversos setores da sociedade brasileira, visto que suscita grande interesse ao envolver a questão do abortamento, noções religiosas e de trazer à baila a questão dos direitos femininos, em face da possibilidade de se conceder à mulher a decisão de continuar ou não a gestar feto anencéfalo. Palavras-chave Aborto, Morte cerebral, Anencefalia 


\section{Introdução}

A anencefalia, um grave defeito embrionário do sistema nervoso central, tem sido alvo de acalorados debates em diversos setores da sociedade brasileira. O tema suscita grande interesse ao envolver a questão do abortamento. Ademais, novamente os direitos femininos são também trazidos à baila, em face da possibilidade de se conceder à mulher a decisão de continuar ou não a gestar feto anencéfalo.

No cerne dos inevitáveis embates, interfere a motivação religiosa, notadamente por parte da Igreja Católica, enfaticamente manifestada. ${ }^{1}$ Esta é a oposição mais ferrenha aos defensores da antecipação do parto de feto anencéfalo. Evidentemente, pelo mesmo direito, podem os argumentos apresentados pelo episcopado brasileiro ser postos em livre discussão crítica.

Importante salientar que a interpretação dos fenômenos naturais é, por muitos, ora reclamada à ciência e ora acatada como produto de revelação divina, a constituir, do ponto de vista epistemológico, uma declarada ambivalência, pois o que se reclama à ciência só é passível de ser obtido pela absoluta negação de qualquer interferência sobrehumana. Esse quinhão de concepção metafísica do mundo, que pode e deve ser livremente expressado, quando não devidamente avaliado e ponderado em suas consequencias, estabelece uma grande vala entre o que existe e o que se sente, entre a realidade e a fantasia e, não raro, confunde, exaspera, instiga controvérsias, dificulta a compreensão, impede o consenso e, não raro, o progresso. É evidente que o direito reclamado de criticar e de opinar deve ser admitido a todos os cidadãos, adeptos de qualquer religião ou de nenhuma.

As discussões que se estabelecem acerca desses temas muitas vezes se esvaem em face da atenção desmedida ao significado de palavras, que passam a constituir focos de discussão. É evidente que se deseja clareza e simplicidade na análise dos problemas e que as palavras devem ser empregadas bem e cuidadosamente. No entanto, nas discussões dessa natureza o interesse maior não deve ser o significado de certos termos, mas o fenômeno biológico em si mesmo, as evidências científicas que o amparam, os problemas que suscitam e que são largamente independentes da terminologia utilizada. O estado de completa nulidade sensorial em que se encontra o anencéfalo, sem memória, sem dor, sem percepção de coisa alguma, sem qualquer chance de sobrevida extra-uterina, não basta, pois a realidade dos fatos é desviada para o problema do termo que deve definilo (feto humano ou coisa?) e não para a sua condição devastadora, absolutamente posta em relevo pela medicina.

O Dorland's Illustrated Medical Dictionary define anencefalia (an sem, negação $+\mathrm{Gr}$. Enkephalos, encéfalo) como ausência congênita da calvária, com perda ou redução dos hemisférios cerebrais a pequenas massas presas à base do crânio. ${ }^{2}$ Embora o vocábulo anencefalia signifique, literalmente, ausência de cérebro, o termo é entendido em medicina, como uma malformação caracterizada pela ausência total ou parcial do encéfalo, sendo esta última forma a mais comum. Calzolari et al. ${ }^{3}$ corroboram essa afirmação ao caracterizar tal malformação pela ausência parcial ou total das estruturas cerebrais e da calvária e pelo desenvolvimento anormal da base do crânio. Isso também se depreende de Purves e colaboradores, que definem anencefalia como um defeito congênito do tubo neural, no qual a maior parte do encéfalo não se desenvolve. 4 Para Best, 5 na anencefalia o cérebro e o cerebelo estão reduzidos ou ausentes, mas o bulbo está presente.

As formas mais comuns de anencefalia, segundo Fishman e Villareal, 6 demonstram o envolvimento do prosencéfalo e de quantidades variáveis de tronco encefálico. O cerebelo, o tronco cerebral e os nervos ópticos podem estar malformados. O hipotálamo está tipicamente ausente e, em consequência, as adrenais são sempre hipoplásicas. Parcelas significativas do crânio estão ausentes, estando também comumente afetados os ossos frontal, temporais e occipital. A ausência da calvária dá a impressão de que os olhos estão edemaciados e o pescoço ausente. $\mathrm{O}$ defeito do crânio pode se estender até ao nível do forame magno e comprometer a coluna cervical. Outras malformações podem estar associadas à anencefalia. Um estudo envolvendo 456 anencefálicos encontrou $12,7 \%$ de malformações associadas, notadamente lábio leporino e/ou fenda palatina ou onfalocele. ${ }^{6}$ No entanto outras malformações podem também estar presentes, inclusive cardíacas, pulmonares, renais e esqueléticas. 6 De acordo com Matew, ${ }^{7}$ a aganglionose - ausência congênita de células ganglionares parassimpáticas - é um achado freqüente. Os anencefálicos nascidos vivos apresentam função de tronco cerebral, com respiração espontânea e, frequentemente, com algumas respostas reflexas, como de sucção. No entanto, eles permanecem inconscientes e, sem cuidados intensivos, a maioria morre dentro de dois dias do nascimento e nenhum sobrevive além de duas semanas. Estas alterações na anencefalia levam a um estado vegetativo e a morte é inevitável, ocorrendo poucas horas após o nascimento ou não além de duas 
semanas do nascimento, ou ainda, como acontece na maioria dos casos, in utero. 6,8

A sensibilidade da ultra-sonografia para o diagnóstico pré-natal de anencefalia chega a $100 \%$ ou quase isso quando realizada por profissionais experientes e, quando feita de rotina, é mais sensível do que as determinações dos níveis séricos de alfa-fetoproteína (AFP). Um estudo mostrou que a ultrasonografia de rotina detectou $96 \%$ de defeitos do tubo neural (DTN) comparado a 78\% pela alfa-fetoproteína. $^{9}$

Os temas éticos suscitados pela anencefalia dizem respeito à vida e à dignidade humanas, como salienta Barroso, 10 entre o direito à vida do feto $\mathrm{e} a$ autonomia das mulheres. As discussões têm incidido sobre abortamento, em face do que se denomina 'antecipação terapêutica do parto'. No Brasil, o fato mais relevante a apoiar a criminalização do abortamento é a teoria da potencialidade fetal, a sugerir que o feto humano representa a possibilidade de uma pessoa humana e, portanto, não pode ser eliminado. A proibição, evidentemente, se estende até as fases iniciais da gestação, embora seja difícil definir um marco inicial para o início da vida. No entanto, a anencefalia veio trazer novo argumento a esta discussão. 11

A criança anencéfala é um ser humano, evidentemente, mas de uma incompletude que lhe retira características comuns aos seres de sua espécie, revelada esta por padrões de comportamento herdados, possibilidades, potencialidades, plasticidade. Não são diferenças de pequena monta, mas naquilo que é fundamental à sobrevivência e caracterização da pessoa. Não existe pessoa sem encéfalo e, portanto, não existe 'vir a ser' em relação aos anencéfalos. Somente a fantasia poética, fundada no espanto, na piedade, na indignação pode conceber algo mais elevado a esses seres - como o de possuir uma alma imortal.

É evidente que este tema desperta emoções muito fortes diante da realidade devastadora da teratologia humana, expressada nesta malformação terrível. Mas não são as emoções legítimas que acompanham as grandes questões humanas, os amores, as coisas estimadas, o espanto diante da impiedade da natureza, que embotam a razão. Constitui erro crasso imaginar que as emoções e sentimentos podem destruir a racionalidade. Não são as emoções legítimas suscitadas pelo tema que haverão de prejudicar a sua apreciação adequada. É mais provável que o contrário ocorresse, caso elas faltassem. Não seria, pois, admissível, supor que tal tema as despertasse nas mais diversas matizes e intensidades, como piedade, intenso amor, tristeza, notadamente em pais de anencéfalos. No entanto, a ignorância dos fenômenos biológicos que concorrem para esta malformação, as pressões religiosas desmedidas, a mentalidade mística excitada por essas pregações, podem desencadear sentimentos infundados de culpa, medo, desgosto, arrependimento nos pais de um anencéfalo.

O comum das pessoas, na sua parcela mais ingênua, tenta crer em certos casos descritos de pretensa longevidade de anencéfalos, na tentativa desesperada de desacreditar a ciência, por ser ela mensageira de uma realidade dolorosa e inevitável, buscando lenitivo na fantasia. Na verdade, não se tratam de casos reais de anencefalia, senão de outras anomalias menos devastadoras. Com a perda do encéfalo, perde o ser humano estruturas como o hipotálamo, tálamo, cerebelo e núcleos da base, que controlam a maioria das funções sem as quais a vida é impossível e absolutamente vegetativa. A ausência do córtex cerebral e do diencéfalo impede o estabelecimento de padrões emocionais, como raiva, excitação, resposta sexual, reação para dor e reação de prazer. Sem córtex cerebral não há armazenamento de memória. Imaginar que existem casos onde anencéfalos respondem a carícias e afagos maternos é produto, pois, da piedade, do amor maternal imenso e da ternura dessas sofridas mães, mas não é verdade que isso ocorra, infelizmente.

O córtex é essencial para a maioria dos processos envolvidos com o pensamento e sem ele a função dos outros centros é imprecisa, pois são seus comandos que tornam as operações desses centros precisas e determinativas. Falta, como já salientado, o hipotálamo, estrutura cerebral que participa ativamente da homeostase e, sem ele, ausência de estimulação hipofisária e, consequentemente, das glândulas por ela estimuladas, como as adrenais, já caracteristicamente atrofiadas ao nascimento. Não há, pois, homeostasia, ou seja, manutenção do meio interno. Não há controle da temperatura corporal na ausência de função hipotalâmica, levando o pequeno organismo malformado a um estado de pecilotermia. ${ }^{12-14}$

Diante de tantas deficiências, o que sobra não sustenta a vida por muito tempo, que fica à cargo de batimentos cardíacos que propelem o sangue e às incursões respiratórias, necessários à hematose e à oxigenação dos tecidos que guardam ainda vitalidade, até que o desequilíbrio total se instale à falta de homeostasia e a criança sucumba inevitavelmente, com ou sem o auxílio de cuidados intensivos.

Não existe presente e nem futuro, pois o anencéfalo não está no mundo, não tem conexão com a realidade e nem qualquer possibilidade de vir a ter. A vida é caracterizada por um conjunto de 
propriedades comuns a todos os organismos, dos procariontes ao metazoário de maior complexidade. Mas, a vida humana não pode ser abarcada em toda a sua plenitude numa definição que inclua todos os seres vivos. Nossa humanidade não nos subtrai do mundo vivo, mas a racionalidade é uma propriedade ímpar que nos distingue e não há definição geral que a incorpore. Daí a aceitação quase universal do conceito de morte neurológica, conferindo à consciência a característica definidora mais relevante de vida nos seres humanos e não os batimentos cardíacos ou a atividade metabólica de tecidos. Um ser que nada pode sentir e para o qual não existe sequer a possibilidade de que venha a sentir coisa alguma, e nem pensar, falar, ouvir está impossibilitado de ser considerado vivo pelo mesmo motivo que se considera morto o indivíduo com morte cerebral. Nada há que justifique a tentativa de preservá-lo para futuro distante ou próximo. A ausência de encéfalo ou apenas a presença de rudimentos dele impede também a ocorrência de fenômenos diversos que caracterizam a vida dos animais, como reprodução (potencial, no caso), movimentos coordenados, regulação metabólica etc. Algumas delas estão presentes, mas de forma desajeitada, irregular, anômala, insegura, instável. Alguns órgãos são normais, mas isso pouco importa visto que não podem atuar isoladamente senão de maneira integrada e dentro de um meio interno que se mantenha constante.

A maternidade humana é um processo com pressupostos comportamentais herdados muito evidentes e muito operantes, a gerar sentimentos e atitudes difíceis de lidar e não constitui simplesmente algo que se pode manipular intelectualmente com facilidade. Constitui um fenômeno biológico que se impõe através de padrões comportamentais que abarcam uma enormidade de condutas e atitudes. $\mathrm{Na}$ verdade, o sentido da vida biológica é a reprodução. A complexidade da qual ela se cerca ao longo da evolução não justifica que esse objetivo tenha se diluído, mas o contrário. Esse processo biologicamente e afetivamente imenso é violentado no caso da anencefalia.

É necessário ter em mente que o conceito de vida abarca duas realidades diferentes, como ressalta Walter. $15 \mathrm{Um}$ deles, diz respeito aos processos metabólicos ou vitais que podem ser chamados de vida humana biológica. $\mathrm{O}$ outro se refere à vida humana pessoal, que inclui a vida biológica, mas que vai, além disso, para incluir outras capacidades distintivamente humanas, como, por exemplo, a capacidade para escolher e pensar. 15 Parece claro que essas capacidades distintivamente humanas, como pensar, por exemplo, é uma atividade do encé- falo e, portanto, um fenômeno biológico. No entanto, é correto que a definição de vida que abrange todos os seres vivos deve ser complementada no caso do ser humano com as capacidades ímpares que lhe distinguem. Não é possível comparar em toda a sua extensão a vida de uma ameba à vida humana, embora deva existir um grupo de características comuns a ambos que os distinguem como seres vivos. Por isso, parece aceitável a conclusão de Walter 15 de que as crianças anencéfalas possuem vida biológica, mas não vida pessoal humana. A aplicação da expressão 'ser biologicamente ativo' parece atender melhor a essa realidade.

Uma tese muito acatada é aquela que leva em consideração a potencialidade, inerente ao embrião, de vir ele a constituir um ser humano. Isso, evidentemente, não deixa de abarcar uma conotação biológica, visto que o desenvolvimento requer um programa específico presente no genoma. É inegável que o zigoto não forma sempre um ser humano. Mas é igualmente verdade que todas as crianças e adultos já foram, ao princípio, zigotos. É também inegável que o zigoto contém um genoma que lhe confere singularidade. Assim, aquilo que se deve admitir se refere exatamente à potencialidade inerente ao embrião de se tornar um ser humano. Cria-se a noção mais aceitável de embrião como pessoa humana potencial. Para Sève, 16 duas coisas são postas em evidência quando se afirma que o embrião é uma pessoa em potencial: a) uma é a de que ela não é capaz de fazer valer a sua dignidade, nem dos seus privilégios, sendo essa tarefa cumprida pelos seus pais ou tutor; b) a outra é que o termo potencial implica em que nosso respeito visa essencialmente o seu futuro de ser humano, ou seja, dirige-se ao presente na medida em que consideramos o seu futuro. Não sendo ele ainda senão uma potencialidade, as consequências éticas disso residem exatamente em respeitar essa potencialidade.

$\mathrm{O}$ termo potencialidade se refere àquilo que existe em estado latente, como possibilidade, mas não como realidade. Existe em latência no embrião a possibilidade de que ele evolua para as formas seguintes conhecidas do desenvolvimento humano. É evidente que, ao menos como princípio regulador, o conceito de potencialidade é perfeitamente aceitável, pois como se pode conceber um adulto sem que tenha sido antes um embrião? O que estuda a embriologia, senão o caminho traçado a partir de formas primevas de vida embrionária? Diferentemente de uma potencialidade teórica, a potencialidade biológica está inscrita no genoma do zigoto e da mãe, pois nesta é genética sua disposição à maternidade e todas as transformações fisiológicas 
que ocorrem para dar condição ao desenvolvimento intra-uterino do embrião. Estar inscrito no genoma não significa, necessariamente, que deverá vir a ser, mas representa uma destinação; se existe no genoma é porque pretende ser, pois não seria possível crer que essa destinação tão importante para a sobrevivência da espécie fosse entregue a circunstâncias totalmente dependentes do acaso ou de epifenômenos. As etapas da embriogênese não padecem de tantas incertezas; cumpridas certas exigências, elas ocorrerão. Isso vem se repetindo a milhões de anos e tem como testemunhas todos os mamíferos que existem e que já existiram na Terra. A maioria dos zigotos perdidos apresenta anomalias cromossômicas e isso não significa "desperdício da gravidez", mas a eliminação de conceptos provavelmente anormais com poucas chances de desenvolvimento, ou seja, uma seleção natural de embriões. 17

Os genes determinam o desejo de procriar, formas de cortejar, transformações fisiológicas para a reprodução e as condições para concepção. A finalidade da vida biológica é, sem dúvida, a reprodução. Afinal, que "aspiração" poderia ter uma molécula de DNA que não fosse produzir uma cópia de si mesma?

No ser vivo, tudo é disposto com vista à reprodução. Uma bactéria, uma ameba, um feto, que destino podem sonhar senão formar duas bactérias, duas amebas, vários fetos? Não existem seres vivos hoje sobre a Terra senão na medida em que outros seres se têm vindo a reproduzir com obstinação há pelo menos dois mil milhões de anos (1971: 15-16). 18

Falar, pois, em potencialidade para o desenvolvimento embrionário, é perfeitamente admissível.

É evidente, porém, que em face de intercorrências diversas, o que é potência pode não vir a ser. No entanto, isso não reprova a admissão de que cada vez que um zigoto se forma em condições normais existe a expectativa de que venha a se desenvolver. Por fim, como pode o homem existir agora sem que tenha existido antes como potência? Do ponto de vista moral esse ser potencial é respeitado em face do seu futuro. E isso faz toda a diferença, pois algumas decisões que se possa tomar se dirigem exatamente ao seu futuro provável.17 Mas qual o futuro provável na anencefalia?

Adicionalmente, é difícil definir qual seja 'o melhor interesse' da criança anencéfala e impossibilitada de devir, pois não existe nada para ela que possa ser bom ou mal, agradável ou desagradável na ausência completa de percepção exterior e interior. Nesta situação, onde a natureza demonstra sua abso- luta indiferença com a piedade, deve-se buscar o melhor interesse dos pais, segundo o desejo deles próprios, ou de outros seres humanos que carecem de doações de órgãos. Amenizar-se-ia, pois, esse fenômeno desastrado, dando-lhe um destino bem mais ameno.

Há, evidentemente, uma defasagem compreensível entre a legislação e os avanços científicos. Talvez não seja relevante acatar a definição estrita de vida e o direito de ser merecedora de sua conservação em termos absolutos, tendo em conta que definir o ser humano sem o seu encéfalo como 'vivo' constitui uma intransponível dificuldade conceitual. Do ponto de vista biológico, o anencéfalo não possui vida de relação (nada percebe do mundo exterior) e nem interna (carece de memória, sensações, emoções).

Questões relevantes, oriundas do conhecimento científico, põem em questão a definição, bem como a determinação do marco inicial da vida humana. Os fenômenos que se seguem após a fecundação são dinâmicos. Não há fusão das membranas dos prónúcleos e sim fragmentação das mesmas, para, em seguida, os centríolos se dividirem e caminharem para os pólos e os cromossomas, agora em dupla dose, se organizarem no equador da célula. Não há intervalos, visto que as transformações descritas são, evidentemente, desencadeadas por eventos moleculares que ocorrem incessantemente. 19 Esses eventos constituem, pois um continuum, ou seja, uma longa série de fenômenos celulares e moleculares em sequência, com mínimas diferenças que se somam e que faz com que o resultado final difira acentuadamente do evento inicial.

Mas há outros fatos a considerar em meio aos possíveis candidatos a marco inicial da vida. Compreendendo como fecundação todos os fenômenos descritos, seria uma resposta plausível que o marco inicial da vida seja a fecundação. No entanto, pode-se argumentar que somente após a desintegração das membranas dos pró-núcleos surge um novo ser, visto que o número diplóide de cromossomos característicos da espécie é alcançado, sem que barreira alguma os separe. Assim, a entrada do espermatozóide na célula não indica, por si só, que existe um zigoto. Sequer ocorre fusão de membranas, mas sim associação de cromossomos homólogos na placa mitótica. Os pró-núcleos se aproximam e formam intergitações, para em seguida suas membranas se desintegrarem. Não se forma, pois, um núcleo diplóide limitado por membrana, como se admitia. A anfimixia não é um processo de fusão, mas de aproximação e desintegração de membranas. $17,19,20$ 
A implantação do blastocisto no endométrio ocorre no sexto dia ${ }^{17}$ e, assim, com maiores probabilidades de sobrevida e de levar adiante as suas potencialidades, torna-se esta estrutura um candidato a marco inicial da vida humana. Entretanto, espermatozóides e ovócitos carregam consigo, individualmente, a capacidade intrínseca de gerar vida. Se forem eles potencialmente geradores de vida, não podem ser considerados acessórios, mas parcelas iguais de vida potencial. Isso nos remete a uma grande regressão, pois os gametas derivam de células diplóides especializadas que sofreram meiose, reclamando também para si o privilégio de serem geradoras de vida em potencial.

Adicionalmente, deve-se ter em consideração que um núcleo diplóide pode ser introduzido em um ovócito anucleado para gerar um novo ser vivo. O núcleo do ovócito é retirado, restando o citoplasma com as informações devidas para ordenar a atividade do núcleo da célula somática intrusa. Isso torna a questão do marco inicial da vida mais problemática ainda, visto que na clonagem não há fecundação. A união sexual e os espermatozóides saem de cena e cedem lugar a uma célula somática e um ovócito sem núcleo. Nesta situação, quando estabelecer que uma nova vida teve início? Quando o núcleo diplóide for introduzido no ovócito ou quando este "zigoto" entrar em segmentação? Não seriam os núcleos das células somáticas introduzidas nos ovócitos, embriões potenciais, visto que foram fruto de singamia e agora dão origem a um novo ser? Isso não eleva muitas células somáticas à condição de embriões em potencial?19,20

A inviolabilidade do direito à vida garantida pela constituição parece estar de acordo com a ideia de que a pessoa começa com a concepção, uma premissa considerada quase necessariamente evidente pela opinião pública. Isso significa que desde a fecundação, emerge um novo ser humano suscetível de direitos, de prerrogativas essenciais da pessoa, jurídicas e éticas, sendo sinônimo de sujeito de direito. 16 Esse enunciado normativo é conveniente ao teólogo, em face da tese de que Deus introduz diretamente a alma no embrião (animação imediata). Ademais, como assinala Sève, 16 como pessoas de bom senso podem duvidar de que existe um novo ser quando o óvulo é fecundado? No entanto, como foi salientado anteriormente, esse evento inicial não é suficientemente claro. Aquilo que parece ser um fenômeno instantâneo, único, quando abordado adequadamente, se revela um processo longo, marcado por fases caracterizadas por uma enormidade de eventos celulares e moleculares, a demonstrar que se trata da gradualidade de uma gênese e não de um evento súbito. 16

A argumentação de que o zigoto humano produzirá, em face do seu equipamento genético, outro ser humano e não um rato, um gato ou uma mosca, corresponde a uma evidência inequívoca, favorável à noção de potencialidade. Mas outros aspectos carecem de análise crítica. $\mathrm{O}$ zigoto humano é uma célula totipotente e, certamente, não produzirá um rato ou uma barata. No entanto, não produzirá, necessariamente, um novo ser humano! A divisão celular, afetada por sinalização defeituosa em face de alterações genéticas, pode gerar um ser informe, como o anencéfalo, ou até um tumor. Outro fato, é que grande parte das células do embrião irão formar a placenta, órgão geneticamente idêntico a ele. Mais ainda, cerca de $50 \%$ a $80 \%$ dos embriões, principalmente em consequências de anomalias cromossômicas, abortam nas condições naturais da reprodução humana nos primeiros dias, sem que as mulheres disso não se dêem conta! Portanto, há muitas fecundações, senão a maioria, que não produzem seres humanos. 16

Em Kant, a pessoa é o sujeito cujas ações são suscetíveis de imputação; é a liberdade de um ser racional. Isso nos remete a questionamentos relevantes, pois esta definição e outras semelhantes excluem aqueles que não são capazes de raciocinar, de desejar por si mesmos. De fato, no desenvolvimento humano, a racionalidade é o ponto mais elevado, o acme da ontogênese humana e que diz respeito à sua singularidade de espécie. Mas ela não está presente no feto, no alienado e no ser vegetativo, como no anencéfalo. A alegação de que o indivíduo em algum desses estados é, do ponto de vista biológico, um exemplar genérico ao possuir características da espécie, não pode ser negado. Mas deveria ser ao mesmo tempo um exemplar singular em face das suas particularidades genéticas, epigenéticas, somáticas, temperamentais. Mas não é.

No entanto, quando se afirma que o embrião é uma pessoa em potencial, isso significa que ela ainda não é capaz de fazer valer a sua dignidade, tarefa que cabe a outros, nomeadamente aos pais, e que ele pode vir a tornar-se um ser humano, uma potencialidade de ser humano. O respeito que a ele se deve dirige-se ao presente na medida em que nele considerarmos o seu futuro. ${ }^{16}$ Necessário se faz, portanto, que ele tenha um futuro presumível.

Em face de argumentos diversos sobre o tema, parece existir uma contradição aparente nas noções de organismo vivo e pessoa morta. Mas isso é apenas aparente, visto que na morte neurológica pode haver vitalidade orgânica, tecidos vivos, atividade biológica. Mesmo fora do corpo os tecidos podem 
permanecer vivos por algum tempo, sem a utilização de qualquer recurso para mantê-los funcionais. Clássicos são os experimentos em físiologia nas escolas de medicina em que isso é posto em evidência com tecidos de outros animais. Assim, a expressão ser 'biologicamente ativo' é usada para evitar o termo vivo, que implicaria, no caso dos seres humanos, na posse de sua atividade cerebral. A morte cerebral e a ausência de cérebro retiram do ser humano todos os atributos de sua humanidade, tornando-o apenas um agrupamento de tecidos vitais. Se a morte neurológica constitui a morte da pessoa por retirar-lhe a consciência irreversivelmente, o que significa não possuir encéfalo?

A atividade da formação reticular, presente em grande parcela no tronco encefálico, ativa o córtex cerebral e mantém a consciência. 21 Em consequência, leões graves e irreversíveis do tronco cerebral impedem o retorno à consciência e isto caracteriza a morte neurológica. Ora, parece claro, pois, que a ausência de córtex cerebral tem o mesmo significado da perda funcional da consciência humana. Como a morte da pessoa corresponde à perda total e irreversível das funções encefálicas, a ausência de encéfalo caracteriza a morte de seu portador.

Não se trata, portanto, da presença de tronco cerebral em atividade como definidor de vida, mas sim da ausência de córtex cerebral, que confere consciência aos humanos, o que torna inútil a presença de atividade do tronco cerebral como mantenedor da consciência. A morte neurológica no anencéfalo não é tida como consequente à ausência de funcionalidade do tronco encefálico, mas à ausência de encéfalo, que retira a possibilidade de consciência, de homeostase, de vida extra-uterina significativa. A presença do tronco encefálico não constituiria uma condição para atribuir vida ao anencéfalo, da mesma maneira que os batimentos cardíacos não definem a ausência ou presença de vida. A morte de uma pessoa existe desde que a mesma esteja impossibilitada de voltar a ter consciência do mundo, dos seus direitos e tanto pior se já é gerada sem que tenha a possibilidade de possuí-los.

Nenhum óbice convincente pode ser posto à afirmação do direito das famílias, notadamente dos pais, decidirem ou não pela antecipação do parto. Não há, portanto, qualquer impedimento ético ou científico para acatar esta afirmação. Mais ainda, inquéritos populares, com o devido esclarecimento e a apresentação de imagens de crianças anencéfalas, demonstram que a maioria das mulheres brasileiras concorda com essas afirmações. O que resta, pois, é a ferrenha oposição da Igreja, cuja influência pode se tornar muito poderosa quando incide sobre magistrados católicos, legisladores católicos, ambivalentes em relação à interpretação dos fenômenos naturais. ${ }^{2}$

Outro argumento contrário é representado pelo que se convencionou chamar de 'bola-de-neve' ou 'premissa da ladeira escorregadia'. Existe um temor de que ocorra com a antecipação do parto na gestação a abertura de um precedente, ou seja, alimenta-se a crença que uma maior tolerância leve obrigatoriamente a uma flexibilização moral que termine inevitavelmente na imoralidade. Ao permitir tal procedimento na anencefalia poder-se-ia cair na leviandade de ceder às pressões de planos para a legalização do abortamento. Esse mesmo consequencialismo ingênuo é utilizado em relação à interrupção da gravidez de anencéfalos, salientando que a sua permissão venha a representar um precedente importante para a legalização total do aborto. Evidentemente, a anencefalia é uma situação muito singular para constituir uma ameaça dessa envergadura, além do que a discussão crítica é uma das preciosidades das sociedades democráticas e nada deve estar imune a ela.

A gestação é um episódio de excepcional relevância na vida da mulher. A partir do momento em que se torna sabedora de que alberga em seu ventre um ser anencéfalo, deve ter o absoluto direito de optar pela manutenção ou não da gestação. Ao exercitar esse direito, faz uso do princípio da liberdade e da autonomia da vontade. A criança que gesta é um ser que nada sente, constituindo um organismo biologicamente ativo, mas sem potencialidade alguma. Resta, pois, o respeito à mãe e aos seus sentimentos. Na hipótese de que ela opte pela antecipação do parto, os quatro princípios universais da bioética se fazem presentes. A sua opção livre e informada pela antecipação; a Justiça que ajudou a quem poderia ser ajudada; a cessação do sofrimento físico e psíquico da mãe. Autonomia, justiça, beneficência seriam princípios devidamente atendidos. Por fim, em tal situação, desconsiderar o seu desejo de antecipar o parto não se chocaria com o princípio da não-maleficência, pois do ponto de vista do anencéfalo não é princípio violado, pelos motivos já sobejamente discutidos.

Parece muito claro que a antecipação do parto em caso de anencefalia não constitui aborto e isso comprova-o a ciência e a aceitação universal de que a ausência irreversível das funções encefálicas constitui morte neurológica e, consequentemente, a aniquilação da pessoa potencial. 


\section{Referências}

1. Conferência Nacional dos Bispos do Brasil. Nota da CNBB sobre Aborto de Feto “Anencefálico" Referente à Argüição de Descumprimento de Preceito Fundamental n. 54 do Supremo Tribunal Federal. Disponível em http://www.cnbb.org.br/site/imprensa/ notas-e-declaracoes/1434-nota-da-cnbb-sobre-aborto-de-feto-anencefalico

2. Dorland's Illustrated Medical Dictionary. $31^{\text {st }}$ ed. Chief Lexicographer Douglas M. Anderson. Philadelphia: Saunders; 2007.

3. Calzolari F, Gambi B, Garani G, Tamisari L. Anencephaly: MRI findings and pathogenetic theories. Pediatr Radiol. 2004; 34: 1012-6.

4. Purves D, Augustine GJ, Fitzpatrick D, Katz LC, LaMantia AS, McNamara JO, Williams SM. Neurociências. 2 ed. Trad. Carla Dalmaz [et al.]. Porto Alegre: Artmed; 2005. p. 476.

5. Best RG. Anencephaly. eMedicine from WebMD. Article Last Updated: Nov 30, 2007. [acesso em 21 ago 2008]. Disponível em: http://www.emedicine.com/neuro/ topic639.htm

6. Fishman MA, Villareal GB. Anencephaly and encephalocele. [acesso em 20 fev 2008]. Disponível em: www.uptodate.com

7. Mathew A. Anencephaly-associated aganglionosis. Am J Med Genet. 1998; 80: 518

8. The infant with anencephaly. The medical task force on anencephaly. New Engl J Med. 1990; 322: 669-74.

9. Monteagudo A, Timor-Trisch IE. Ultrasound diagnosis of neural tube defects. UpToDade. Disponível em http://patients.uptodate.com/topic.asp?file=pregcomp/972 5\#3 [2008 mar 02]

10. Barroso LR. Gestação de fetos anencefálicos e pesquisas com células-tronco: dois temas acerca da vida e da dignidade na Constituição. Panóptica. 2007; 1: 1-37. [acesso em 2 mar 2008]. Disponível em: http://www.panoptica.org/marco_abril07pdf/ano1 n\%5B15 D.7_mar.-abr.2007_1-37.pdf
11. Diniz D. Selective abortion in Brazil: the anencephaly case. Dev World Bioeth. 2007; 7: 64-7.

12. Guyton AC, Hall JE. Textbook of Medical Physiology. 17th ed. Philadelphia: Elsevier Saunders; 2006. p. 894.

13. Brandão ML. Psicofisiologia: as bases fisiológicas do comportamento. São Paulo: Editora Atheneu; 2001. p. 198204.

14. Gazzaniga MS, Iury RB, Magnun GR. Neurociência cognitiva. 2 ed. Trad. Angelica Rosat Consiglio et al. Porto Alegre: Artmed; 2006. p. 88-113.

15. Walter JJ. Life quality in the clinical decisions. In: Encyclopedia of Bioethics. Reich WT, editor. v. 2. New York: Simon \& Schuster Macmillan; 1995. p. 1356-7.

16. Sève L. Para uma crítica da razão bioética. Trad. Maria José Figueiredo. Lisboa: Instituto Piaget; 1994.

17. Moore KL, Persaud TVN. Embriologia clinica. 6 ed. Rio de Janeiro: Editora Guanabara; 2000.

18. Jacob F. A lógica da vida. Tradução: Serrano JJ, Palmerim MJ. Lisboa: Publicações Dom Quixote; 1971. p. 15-16.

19. Alberts B, Bray D, Johnson A, Lewis J, Raff M, Roberts K, Walter P. Molecular Biology of the cell. 4 ed. 2002. [acesso em 18 mar 2008]. Avalilable from: http://www.ncbi.nlm.nih.gov/sites/entrez?db=books\& cmd $=$ fertilization $\% 20$ AND $\% 20$ mboc $4 \% 5$ Bbook $\% 5$ D\&dop tcmdl=TOCView.Search\&term

20. Ruiz R, Cuneo MF, Lacuara JL, editors. Fertilização. In: Cingolani HE, Houssay AB. Fisiologia humana de Houssay. Trad. Adriene Belló Klein et al. 7 ed. Porto Alegre: Artmed; 2004. p. 718-9.

21. Pazo JH, editor. Fisiologia do sistema somatosensorial. In: Cingolani HE, Houssay AB. Fisiologia humana de Houssay. Trad. Adriene Belló Klein et al. 7 ed. Porto Alegre: Artmed; 2004. p. 811-40.

Recebido em 8 de abril de 2010

Versão final apresentada em 28 de maio de 2010

Aprovado em 20 de setembro de 2010 